\title{
Analysing innovation-driven enterprises' stakeholders in two spatial ICT ecosystems
}

\author{
Jukka Majava, Tuomo Kinnunen, Del Foit, Pekka Kess (2017) "Analysing innovation- \\ driven enterprises' stakeholders in two spatial ICT ecosystems", International Journal \\ of Management and Enterprise Development, Vol. 16, No. 3, pp. 207-220
}

The final publication is available at: https://doi.org/10.1504/IJMED.2017.085041

\section{Jukka Majava*, Tuomo Kinnunen, Del Foit ${ }^{\star *}$ and Pekka Kess}

Industrial Engineering and Management

University of Oulu

P.O. Box 4610

FI-90014, Finland

**Rady School of Management

University of California San Diego

9500 Gilman Dr., La Jolla, CA 92093

USA

E-mail: jukka.majava@oulu.fi

E-mail: tuomo.kinnunen@oulu.fi

E-mail: dfoit@ucsd.edu

E-mail: pekka.kess@oulu.fi

*Corresponding author

\begin{abstract}
Innovation-driven enterprises (IDEs) engage with various stakeholders during new product development and commercialisation. Spatial ecosystems in which these enterprises operate provide them with the local business environment for new innovation development. Our study analyses IDEs' stakeholders in two spatial information and communication technology (ICT) business ecosystems: one in San Diego, California, USA and the other in Oulu, Finland. The study analyses the stakeholders' presence and their roles to support innovation. The critical stakeholders for supporting innovation-driven enterprises, such as providers of different forms of capital and research institutes, are identified. Our findings suggest that IDEs should exploit the spatial ecosystems by interacting with various stakeholders and by gaining access to local resources to create new innovations. The results of the study are beneficial both for managers of new innovation-driven ventures and decision-makers designing and implementing innovation policies.
\end{abstract}

Keywords: innovation, business ecosystem, stakeholder, innovation-driven enterprise (IDE), spatial context, information and communication technology (ICT). 


\section{Author}

Reference to this paper should be made as follows: Majava, J., Kinnunen, T., Foit, D. and Kess, P. (201X) 'Analysing innovation-driven enterprises' stakeholders in two spatial ICT ecosystems', Int. J. of X, Vol. XX, No. YY, pp.XXX-XXX.

Biographical notes: Jukka Majava (Dr Sc) works as a university lecturer in Industrial Engineering and Management at the University of Oulu, Finland. His industrial experience includes technology and ecosystem marketing, partner and project management, and business and supply chain development at Nokia Corporation. He has research interests in product innovation, business networks and supply chain development.

Tuomo Kinnunen (MSc Tech) is a researcher in Industrial Engineering and Management at the University of Oulu. He has a master's degree in industrial engineering and management. Mr. Kinnunen has worked on several international research projects. His research work and interests include product development and business development, covering different angles.

Del Foit (MBA, BSc) is a lecturer at the University of California, Rady School of Management. He has over 30 years of experience in the life sciences industry, encompassing executive management responsibilities for operations, quality assurance, materials management, product development, information technology, distribution and customer support. During his professional career, Del held positions as chief operating officer at Sequenom, Inc., vice president of North American operations at Roche Diagnostics and director of operations at the Infectious Disease Business Unit, Ortho Clinical Diagnostics.

Pekka Kess (Dr Sc, Dr Eng) is a professor of industrial engineering and management at the University of Oulu. He has extensive managerial experience from both universities and industrial enterprises. He has worked in managerial positions in chemical, steel and electronics industries, as well as in the software business. He has been an active project evaluator in the European Commission, as well as a manager of international research and development projects. His research areas cover business ecosystems, strategic management, production organisations, knowledge management with specialisation in knowledge transfer, and e-learning.

This paper is a revised and expanded version of a paper entitled 'Ecosystem stakeholder analysis: an innovation-driven enterprise's perspective' presented at MakeLearn \& TIIM Joint Conference, Timisoara, Romania, 25-27 May 2016.

\section{Introduction}

The importance of entrepreneurship and innovation for local economy is undisputable. Entrepreneurship and innovation are also highly affected by different contexts, such as spatial dimension (Autio et al., 2014). While contextual differences are relevant, new ventures all over the world have to address many similar challenges during innovation and new business creation. Especially enterprises that target global markets cannot often succeed on their own in brutal competition; they need to create and maintain relationships with other actors in the networks to create attractive offerings (Majava et al., 2013). The competition has shifted from a company and an industry level towards a business ecosystem level (Iansiti, 2004; Moore, 1993).

While the local economies benefit from entrepreneurship, one must understand that not all new ventures are alike: small and medium enterprises (SMEs) target mainly local and regional 
Title

markets, whereas innovation-driven enterprises (IDEs) typically focus on global markets (Aulet and Murray, 2013). Our study focuses on the latter category and elaborates the differences between these two enterprise types in the next section.

IDEs need to collaborate with various stakeholders during the innovation and new product development (NPD) process. The typical stakeholders include customers, suppliers and other partners, competitors, and different institutions, including universities (Belderbos et al., 2004; Un et al., 2010). However, many other stakeholders also contribute to the innovation and NPD.

IDEs are highly important for the local, regional and national economy, because they are capable of generating more new jobs and exports than SMEs (Aulet and Murray, 2013). Therefore, many governments have aimed to create successful start-up ecosystems with innovative firms (Etzkowitz and Leydesdorff, 2000). However, the creation of successful spatial ecosystems has proved to be very difficult in practice (e.g. Kenney, 2000; Saxenian, 1994). The purpose of this study is to address the aforementioned issue by studying the stakeholders in spatial ecosystems from an IDE's perspective in two information and communication technology (ICT) oriented regions: San Diego, California, USA and Oulu, Finland. As Appendix 1 indicates, these two locations are very ICT-intensive based on international patent (PCT) applications per inhabitant. Instead of company-specific customers, suppliers, and partners, we focus on the other stakeholders that support IDEs in new innovation creation and commercialisation. Accordingly, the following research questions are set for our study:

1. What stakeholders - apart from customers, suppliers, and other business partners support IDEs in innovation creation in spatial ecosystems?

2. What is the stakeholders' presence and how do they support IDEs in the cases under study?

We address the research questions above through a literature and empirical study. In the literature section we discuss stakeholders, business networks and ecosystems, spatial innovation, and IDEs. In the empirical part of the paper we explore the IDEs' stakeholders through a case study. After the analysis, conclusions are made.

\section{Literature}

2.1. Stakeholders, business networks, and spatial ecosystems

Various definitions for the term "stakeholder" can be found in the literature (Aaltonen and Kujala, 2010; Mitchell et al., 1997). When defined broadly, stakeholder is "any group or individual who can affect or is affected by the achievement of the organisation's objectives" (Freeman, 1984). In narrow definitions stakeholders are described in terms of direct relevance to the company's core economic interests (Mitchell et al., 1997). Stakeholders can be categorised in many ways, such as primary or secondary, owners and non-owners of the company, those in a voluntary or involuntary relationship with the company, resource providers to or dependents of the company (Mitchell et al., 1997). In new product development context, stakeholders enable product delivery to the end users and the support throughout the product's life cycle (Ulrich and Eppinger, 2012).

A lot of research has been done on different collaboration models, networking, and related interactions (e.g. Dermol and Breznik, 2012). While business to business collaboration can simply be buying products or services from other businesses, industry collaboration can reach out to different forms of business networks and ecosystems. Majava et al. (2013) have compared characteristics of different collaboration concepts. The collaboration concepts were noticed to 


\section{Author}

differ in terms of the following factors: type of members, goal, coordination, boundaries, change dynamism, nature of relationships, role of knowledge, and competitors.

Business ecosystems tie different stakeholders (actors) together through knowledge flows and shared value creation processes (Iansiti and Levien, 2004). Ecosystems' rules result from the coevolution and interactions between the actors. Other actors adjust to the rules set by the lead actors (keystones or platform leaders) that may be replaced by others in the future. However, the other stakeholders, such as niche players and intermediaries, value the leaders that enable the members to move toward a shared future and benefits (Iansiti and Levien, 2004; Moore, 1993; Moore, 1996). Companies in business ecosystems develop mutually beneficial relationships with various stakeholders including, for example, customers, suppliers, and competitors. The coevolution takes place around a new innovation: organisations cooperate and compete to support new products, to satisfy customer needs, and finally to create succeeding innovations (Iansiti and Levien, 2004). Innovation and coevolution can be considered to be the main factors affecting business ecosystems (Majava et al., 2013).

Due to the importance of innovation to economic development, many regions try to achieve an innovation environment that includes university spin-offs, initiatives for knowledge-based economic development, and boundary-spanning and partnerships between companies, government laboratories, and academic research groups (Etzkowitz and Leydesdorff, 2000). Innovativeness and success of certain geographical regions can be viewed from three different perspectives: having universities as anchors of regional clusters, social networks as enabling factor, and institutional frameworks (Casper, 2013). On the other hand, Hwang and Horowitt (2012) stress talent diversity, trust across social barriers, motivations above short-term rationality, and social norms that stimulate rapid collaboration and experimentation.

\subsection{Innovation-driven enterprises and firm growth stages}

Aulet and Murray (2013) define innovation-driven enterprises (IDEs) to be enterprises that "pursue global opportunities based on bringing to customers new innovations that have a clear competitive advantage and high growth potential." Furthermore, by innovation they mean newto-the world ideas in the technical, market, or business model domains. Aulet and Murray (2013) stress not using the term "technology-driven", because in their view, innovation is not limited to technology. Table 1 highlights the key differences between SME entrepreneurship and IDE entrepreneurship.

Table 1. Differences between SME and IDE entrepreneurship (modified from Aulet and Murray, 2013)

\begin{tabular}{ll}
\hline SME... & IDE... \\
\hline focus on addressing local and regional markets & focus on global markets \\
$\begin{array}{ll}\text { innovation is not necessary to establishment and } \\
\text { growth, nor is competitive advantage }\end{array}$ & $\begin{array}{l}\text { is based on some sort of innovation } \\
\text { (technology, process, business model) and } \\
\text { potential competitive advantage }\end{array}$ \\
$\begin{array}{l}\text { create "non-tradable" jobs generally performed } \\
\text { locally (e.g. restaurants, service industry) }\end{array}$ & $\begin{array}{l}\text { create "tradable jobs" that do not have to be } \\
\text { performed locally }\end{array}$ \\
$\begin{array}{l}\text { are most often family businesses or businesses } \\
\text { with very little external capital }\end{array}$ & $\begin{array}{l}\text { have more diverse ownership bases including } \\
\text { wide array of external capital providers }\end{array}$
\end{tabular}


Title

typically grows at a linear rate. When more money is invested, the system (revenue, cash flow etc.) responds quickly in a positive manner. starts by losing money, but if successful will grow exponentially. Requires investment, but the system does not respond quickly.

Table 1 is beneficial in illustrating the fundamental differences between SMEs and IDEs. However, it should be noted that the characteristics may not be that controversial in practice. For the purpose of our study, we define the most relevant differences to include that IDEs are based on an innovation and a time gap exists between investment and revenue. An IDE typically goes through certain development stages before revenue is gained.

The growth and development of firms have been studied extensively from various perspectives in the last decades (Muhos, 2015). A typical firm development model covers a birth, survival, growth, maturity and stability stages, whereas some models contain the entire lifecycle including a potential decline and death (Illés et al., 2015). One of the most classical growth models was introduced by Churchill and Lewis (1983). This model includes a five-stage framework through which small companies pass. The stages include existence, survival, success, take-off, and resource maturity. In each stage, the organisational goals, business size, diversity, complexity, and management style vary. The purpose of the framework is to evaluate and tackle the stage-specific problems and future challenges for the enterprise. Although the framework is generic, Churchill and Lewis (1983) note that enterprises differ; in case of high-technology startups, venture capital is used to accelerate the firm development through the stages.

The five-stage framework described above is beneficial and can still be applied today, but the special characteristics of IDEs (Aulet and Murray, 2013) should be acknowledged. For example, a typical evolution process for IDEs in the life sciences sector starts with a technology based idea, which has originated from government funded basic research at a university or a research institute. Early stage work, such as intellectual property protection, is needed to support the commercialisation of the invention. The invention could then be licensed to an existing company or a new start-up. Accelerators and incubators may support the start-up phase, and seed funding is typically acquired from angel investors. If the company is successful, more funding is acquired from venture capitalists, new employees are recruited, and in the long-term an initial public offering (IPO), a merger, or acquisition by another company may take place (Majava et al., 2016).

\section{Method}

This study utilises a holistic research strategy based on literature findings and the case study method (Yin, 2009). As the phenomenon under study is within the real-life context and the boundaries between phenomenon and context are not clearly evident, we utilise multiple sources of evidence. The empirical data was collected from two spatial business ecosystems: San Diego, California, USA and Oulu, Finland. While these two locations differ in terms of population size and business environment, they also share many similarities. These include being part of developed economies, having a remote distance from their capitals, and very strong information and communication technology (ICT) sectors. Thus, these ecosystems were considered to provide interesting points of similarities and juxtapositions.

The data collection in both cases involved field research, using online resources, participating in events, following local media, and meeting local incubators, accelerators, and entrepreneurs. The analysis of each case as a separate entity was followed by a cross-case analysis. The data 
Author

analysis was conducted by using qualitative approach (Eisenhardt, 1989). The literature findings and the data collected were utilised to create a conceptual framework that is presented in the results section.

\section{Results}

\subsection{San Diego innovation ecosystem}

The city of San Diego is located in Southern California, USA. With approximately 1.4 million people, San Diego is the eighth largest city in the United States and the second largest in California. By 2020, the city's population is forecast to be over 1.5 million, with 3.5 million people in the entire county (The City of San Diego, 2016).

San Diego started to focus on research and development in the 1960s and this development was supported by federal government investments. In the mid-1980s, the region's research institutes had created a critical mass of R\&D capacity and international firms and venture investors became attracted to the area. Additionally, three pioneer start-ups that included Linkabit (wireless), ISSCO (computer graphics), and Hybritech (biotechnology), had a key role in San Diego's development. In the mid-1980s San Diego suffered from reductions in the military sector, and local leaders recognised the need to accelerate innovation; an intermediary organisation called CONNECT was established. The CONNECT organisation has been very successful in catalysing local innovation. (Walshok and Shragge, 2014).

Currently, San Diego is especially strong in wireless technology and life sciences sectors (Walshok and Shragge, 2014; Walshok and West, 2014). The largest research and education institute, University of California San Diego, has over 31000 students (UCSD, 2016). The lead company in the ICT sector is Qualcomm that employs approximately 10000 people locally (Majava et al., 2016). According to CONNECT (2015), 248 software and 86 communications, computer and electronics start-up companies were established in San Diego county in 2014. Local companies in the aforementioned fields employ approximately 70000 people, whereas the total number of high-tech employees in San Diego is 148000.

\subsection{Oulu innovation ecosystem}

The city of Oulu is located in Northern Finland. Oulu region includes seven municipalities with approximately 242000 inhabitants and the region has committed stakeholders to support innovation. The University of Oulu was established in 1958. Oulu Innovation Alliance (OIA) was established in 2009 and includes the city of Oulu, University of Oulu, Oulu University of Applied Sciences, VTT Technical Research Centre of Finland, Technopolis Plc, and Finnish Environment Institute (OIA, 2016).

The strongest industry sectors in the region include electronics, information technology (IT), software, and technical services (BusinessOulu, 2015). Oulu region has 15000 high-tech jobs, 7500 research and development (R\&D) experts, and over 400 information and communication technology (ICT) companies. University of Oulu has 16000 students, whereas Oulu University of Applied Sciences has another 8000 (Lehikoinen, 2015).

The economic development in the region, as well as in the whole Finland, has been weak in recent years (BusinessOulu, 2015). One of the main reasons for this is the downsizing of Nokia's mobile phone business, which employed approximately 2500 people in Oulu region in 2010. The mobile phone business was sold to Microsoft in 2014; today, Microsoft employs significantly 
Title

less people in Finland and none of the employees are based in Oulu. However, the problems of Nokia's mobile phone business has led to an increase in the number of start-ups in Finland, as talented employees have begun their own businesses. In Oulu region, there are around 300 startup companies and several international ICT companies have established R\&D sites in Oulu in 2014 and 2015; Nokia's mobile networks business has also very strong presence in Oulu with its 2500 employees (Lehikoinen, 2015).

\subsection{Ecosystem stakeholders that support IDEs}

The literature findings and the data collected during the case studies have been synthesised in Table 2 below. The purpose of the Table 2 is to illustrate the phases through which new innovations are developed, the typical stakeholders that are involved, as well as to provide concrete examples of stakeholders in San Diego and Oulu innovation ecosystems.

Table 2. Ecosystem stakeholders that support IDEs in the innovation process

\begin{tabular}{|c|c|c|c|c|}
\hline Phase & Description & Stakeholders & San Diego examples & Oulu examples \\
\hline $\begin{array}{l}\text { 1. Idea generation } \\
\text { and technology } \\
\text { development }\end{array}$ & $\begin{array}{l}\text { Basic research } \\
\text { Applied research }\end{array}$ & $\begin{array}{l}\text { Universities } \\
\text { Research } \\
\text { institutes } \\
\text { Large companies } \\
\text { and SMEs } \\
\text { R\&D funding } \\
\text { bodies }\end{array}$ & $\begin{array}{l}\text { University of } \\
\text { California San Diego } \\
\text { (UCSD) } \\
\text { San Diego State } \\
\text { University (SDSU) } \\
\text { Qualcomm } \\
\text { Federal and state } \\
\text { governments }\end{array}$ & $\begin{array}{l}\text { University of Oulu } \\
\text { (UoO), Oulu } \\
\text { University of } \\
\text { Applied Sciences } \\
\text { (OUAS),VTT and } \\
\text { other OIA } \\
\text { members } \\
\text { Nokia } \\
\text { TEKES, EU }\end{array}$ \\
\hline $\begin{array}{l}\text { 2. Early stage } \\
\text { work to support } \\
\text { commercialisation }\end{array}$ & $\begin{array}{l}\text { IP protection } \\
\text { Exploring } \\
\text { potential } \\
\text { applications }\end{array}$ & $\begin{array}{l}\text { Innovation } \\
\text { service offices } \\
\text { Incubators } \\
\text { Pre-accelerators }\end{array}$ & $\begin{array}{l}\text { UCSD Office of } \\
\text { Innovation and } \\
\text { Commercialization } \\
\text { EvoNexus } \\
\text { CyberTECH iHive } \\
\text { Von Liebig Center } \\
\text { Rady StartR and my } \\
\text { startupXX }\end{array}$ & $\begin{array}{l}\text { UoO innovation } \\
\text { services } \\
\text { Yritystakomo } \\
\text { Business Kitchen }\end{array}$ \\
\hline $\begin{array}{l}\text { 3. Start-up } \\
\text { establishment }\end{array}$ & $\begin{array}{l}\text { Business model } \\
\text { development and } \\
\text { firm } \\
\text { establishment } \\
\text { Acquisition of } \\
\text { pre-revenue (pre- } \\
\text { seed) funding }\end{array}$ & $\begin{array}{l}\text { Business angels } \\
\text { Incubators } \\
\text { Pre-accelerators } \\
\text { Business services } \\
\text { providers }\end{array}$ & $\begin{array}{l}\text { Friends, family, and } \\
\text { fools (FFF) } \\
\text { Unorganised angels } \\
\text { Rady Venture Fund } \\
\text { EvoNexus } \\
\text { CyberTECH iHive } \\
\text { Von Liebig Center } \\
\text { Rady StartR and my } \\
\text { startupXXProcopio } \\
\text { Knobbe Martens } \\
\text { DLA Piper }\end{array}$ & $\begin{array}{l}\text { Friends, family, } \\
\text { and fools (FFF) } \\
\text { Unorganised } \\
\text { angels } \\
\text { Business Kitchen } \\
\text { Yritystakomo } \\
\text { Oulu region } \\
\text { enterprise agency } \\
\text { Castren \& Castren } \\
\text { Kolster }\end{array}$ \\
\hline $\begin{array}{l}\text { 4. Seed / early } \\
\text { stage funding }\end{array}$ & $\begin{array}{l}\text { Acquisition of } \\
\text { the seed and } \\
\text { early stage }\left(1^{\text {st }}\right.\end{array}$ & $\begin{array}{l}\text { Business angels } \\
\text { VC firms } \\
\text { Funding agencies }\end{array}$ & $\begin{array}{l}\text { San Diego Tech Coast } \\
\text { Angels } \\
\text { Rady Venture Fund } \\
\text { Avalon Ventures }\end{array}$ & $\begin{array}{l}\text { FiBAN } \\
\text { Butterfly Ventures } \\
\text { TEKES, EU } \\
\text { ELY centre }\end{array}$ \\
\hline
\end{tabular}




\begin{tabular}{|c|c|c|c|c|}
\hline & $\begin{array}{l}\text { stage } / 2^{\text {nd }} \text { stage) } \\
\text { funding }\end{array}$ & $\begin{array}{l}\text { Business services } \\
\text { providers } \\
\text { Accelerators }\end{array}$ & $\begin{array}{l}\text { Federal government } \\
\text { (SBIR \& STTR) } \\
\text { Co-working alliance } \\
\text { CONNECT } \\
\text { Springboard } \\
\text { Procopio } \\
\text { DLA Piper }\end{array}$ & $\begin{array}{l}\text { Finnvera } \\
\text { Njetwork Inn } \\
\text { Technopolis } \\
\text { BusinessOulu } \\
\text { Nestholma } \\
\text { Fidescon } \\
\text { Castren \& Castren }\end{array}$ \\
\hline $\begin{array}{l}\text { 5. Growth phase / } \\
\text { later stage funding }\end{array}$ & $\begin{array}{l}\text { Commercial } \\
\text { success } \\
\text { Later stage } \\
\text { funding rounds } \\
\left(3^{\text {rd }} \text { stage/pre- }\right. \\
\text { IPO) } \\
\text { More people are } \\
\text { recruited }\end{array}$ & $\begin{array}{l}\text { Funding agencies } \\
\text { Investors } \\
\text { Local talent pool } \\
\text { Trade } \\
\text { associations \& } \\
\text { services } \\
\text { organisations }\end{array}$ & $\begin{array}{l}\text { Finistere Ventures } \\
\text { Investors from San } \\
\text { Francisco Bay Area } \\
\text { and New York } \\
\text { Qualcomm, UCSD, } \\
\text { SDSU } \\
\text { CONNECT }\end{array}$ & $\begin{array}{l}\text { TEKES } \\
\text { Finnvera } \\
\text { Investors outside } \\
\text { of spatial } \\
\text { ecosystem } \\
\text { Nokia, Tieto, UoO, } \\
\text { OUAS } \\
\text { Business Oulu }\end{array}$ \\
\hline $\begin{array}{l}6 . \text { IPO, } \\
\text { acquisition or } \\
\text { merger }\end{array}$ & $\begin{array}{l}\text { Initial public } \\
\text { offering, sale of } \\
\text { the company or } \\
\text { merger with } \\
\text { another entity }\end{array}$ & $\begin{array}{l}\text { Large investors } \\
\text { \& financial } \\
\text { institutions } \\
\text { Legal services } \\
\text { Large companies }\end{array}$ & $\begin{array}{l}\text { Stakeholders mainly } \\
\text { from San Francisco } \\
\text { Bay Area and New } \\
\text { York }\end{array}$ & $\begin{array}{l}\text { Stakeholders } \\
\text { mainly outside of } \\
\text { spatial ecosystem }\end{array}$ \\
\hline
\end{tabular}

As can be seen in Table 2, the first phase of the process can include basic or applied research that is typically publically funded and carried out at universities and research institutes. Local companies may also conduct private research or be involved in open innovation projects. In San Diego's case, the public funding often comes from federal (National Science Foundation) and state (e.g. California Institute for Telecommunications and Information) sources and the research is carried out at, for example, UCSD. Oulu ecosystem, in turn, receives research funding from TEKES (Finnish funding agency for innovation) and EU programs including Horizon 2020. The research work is typically carried out at University of Oulu (UoO), VTT Technical Research Centre of Finland, or Oulu University of Applied Sciences (OUAS). Other OIA members and companies may also contribute to research projects.

The second phase involves exploring potential applications and intellectual property (IP) protection if necessary. In this phase stakeholders in San Diego ecosystem include UCSD Office of Innovation and Commercialization, incubators (e.g. EvoNexus and CyberTECH iHive), and pre-accelerators, such as UCDS's Von Liebig Center and Rady StartR and mystartupXX. The Oulu ecosystem contains similar stakeholders: University of Oulu innovation services and incubator and pre-accelerator programs at Yritystakomo and Business Kitchen, which is UoO and OUAS' joint entrepreneurship hub. However, it should be noted that phases 1 and 2 of the process are optional, since innovations can also be process- or business model-based and/or utilise existing technologies.

In the third phase, a business model is developed further and a company is established. Preseed funding for the new start-up is typically acquired from individuals and business angels. Incubators and pre-accelerators may support the process. Legal services including the formation of legal entity and funding and IP related services are also needed. In addition, stakeholders, such as Oulu region enterprise agency, may be involved in helping with the practical arrangements of firm establishment. The third phase of the process can be considered to correspond with Existence stage in the small company model developed by Churchill and Lewis (1983). In this stage the 
Title

organisation is very simple and the founder is involved in all activities, such as identifying potential customers and investors.

The fourth phase of the process involves acquisition of the seed and early stage funding from business angels or venture capital firms. Examples of these stakeholders in San Diego ecosystem include San Diego Tech Coast Angels, the largest organised angel network in USA, Rady Venture Fund, and Avalon Ventures. The corresponding stakeholders in Oulu ecosystem include Finnish Business Angel Network (FiBAN) and Butterfly Ventures. Public funding may also play a role; the IDEs in San Diego ecosystem may become supported by federal government's Small Business Innovation Research (SBIR) and Small Business Technology Transfer programs. In Oulu ecosystem the IDEs can apply public funding for example through TEKES Hilla (High-tech ICT Leverage from Long-term Assetization) program and the EU SME instrument. ELY centre (Centre for Economic Development, Transport and the Environment) and Finnvera (a specialised financing company owned by the State of Finland) may also become involved. The company typically needs business services, such as legal and financial services and office facilities that are available through various stakeholders. In the seed stage, the IDE has a product or concept under development, but is typically not fully operational. In the early stage, the company often has a product or service in testing or pilot production. The product may even be commercially available but the revenues are limited. In order to attract angel and VC investments the business model and operations can be developed further with accelerator programmes, such as CONNECT Springboard in San Diego and Nestholma in Oulu. This phase can be considered to correspond with Existence stage and in some cases Survival stage, where the still simply-structured organisation has demonstrated a potential for being a workable business entity and the focus starts to shift from the existence to managing revenues and expenses (Churchill and Lewis, 1983).

If the success continues, the IDE enters the fifth phase where more funding is acquired from investors and funding agencies. In the growth phase, the company's offering is commercially available. In spite of growing revenues the company may be unprofitable. In the later stage, the offering is widely available and the cash flow often becomes positive. New employees are recruited from the local talent pool that includes large companies and universities. The company's market interests and export efforts may be supported by stakeholders, such as CONNECT in San Diego and BusinessOulu, the City of Oulu's organisation that is responsible for industry policy implementation and development services for companies. The fifth phase can be considered to correspond with Success and Take-off stages (Churchill and Lewis, 1983). In the Success stage, the owners must make decisions between growth and profitability, whereas in the Take-off stage the key issues include how to grow rapidly and finance the growth.

In case the business continues to grow, the IDE enters the sixth phase, and an initial public offering (IPO), a merger, or acquisition by another company may occur. This phase can be considered to correspond with Resource maturity stage in the model by Churchill and Lewis (1983). The key issue in this stage is how to sustain the advantages of flexibility and entrepreneurial spirit while making the operations more efficient through management systems typically used in large companies. The stakeholders supporting the last phase of the process are typically located outside the spatial ecosystems. In case of San Diego, the stakeholders are often located in the capital rich San Francisco Bay area and New York.

\section{Discussion and conclusions}

Innovation-driven enterprises (IDEs) must engage with various stakeholders to create new products and commercialise them, and different spatial ecosystems provide these firms with local 
conditions for innovation creation. This study explored IDEs' stakeholders in spatial business ecosystems. The required stakeholders' presence and their roles in supporting innovation were analysed in a case study that included two spatial ICT ecosystems: San Diego, California, USA and Oulu, Finland.

It should be emphasised that the IDE evolution process described in the results section is only a generic conceptualisation. Furthermore, due to a large number of stakeholders only some examples of them were included in Table 2. However, the conceptualisation presented in the results section is beneficial for analysing the existence and roles of different stakeholders in the innovation process. IDEs need to combine many skills and resources (Aulet and Murray, 2013); thus, they should exploit the spatial ecosystems through interacting with various stakeholders to benefit from the local resources. However, not all the required resources may reside spatially.

It should also be noted that both of the studied ecosystems have some weaknesses and risks in terms of stakeholders. In San Diego's case the main weakness is the fact that the vast majority of financial resources in USA are mainly located outside the spatial ecosystem. In addition, one could argue whether Qualcomm with its 10000 employees is too a dominant player in the ecosystem. Despite the benefits of having a successful lead company the big size of one actor may also be a risk for the spatial ecosystem, if it hinders the growth of other companies. The worst case scenario is that the lead company suddenly fails and ceases to exist as happened for Nokia's mobile phone business in Finland. However, in San Diego the growing presence of industry venture funds and the convergence of ICT and life sciences do mitigate the weakness and risk noted here. Major pharmaceutical companies including Pfizer, Novartis, Janssen (Johnson \& Johnson) are present in San Diego with venture and incubator activities. In addition, Qualcomm has established The Qualcomm Life Fund that focuses on investing in wireless health start-ups. While Qualcomm is a major influence in San Diego, other prominent ICT players such as ViaSat, Kyocera Americas, and SAIC are also present.

Oulu ecosystem also includes some weaknesses in terms of stakeholders, especially in phase 2 (early stage work and technology transfer) and phase 5 (later stage funding) of the process. Activities to strengthen the phase 2 have already been initiated. For example, TellUs innovation arena was recently established in Linnanmaa campus of University of Oulu. This will increase the presence of important stakeholders, such as BusinessKitchen, at the university campus. The weakness in later stage funding is a generic weakness of Finland. As concluded in a recent study, "Finland's weak point is lack of a functioning venture capital (VC) market and ecosystem especially in the later-stage VC in terms of quality and investment volumes" (Saarikoski et al., 2014). The bottlenecks include lack of commercialisation know-how, small investment sizes, large share of public sector, and illiquidity of exit markets. With regards to risks, Oulu ICT ecosystem is still highly dependent on Nokia. Despite the increase in the number of start-ups after Nokia discontinued its mobile phone business, Nokia's mobile networks business with its 2500 employees is still by far the largest private employer in Oulu.

While the studied spatial ecosystems differ especially in the size of population and domestic market they also share similarities. In addition to the similar stakeholders that were identified in our study both of the ecosystems have strong R\&D resources and a solid track record in creating new inventions. Furthermore, both San Diego and Oulu must compete with locations that can provide greater R\&D and financial resources, i.e. San Francisco Bay area (Silicon Valley) and Helsinki, respectively. Both San Diego and Oulu have succeeded fairly well in this competition, which indicates that spatial ecosystems in remote locations can also be viable.

Finally, it should be stressed that this study focused on specific ecosystem stakeholders only. In addition to the stakeholders that were analysed in the study, many other factors contribute to the creation of successful ecosystem. The holistic entrepreneurship ecosystem domains can be 
Title

considered to include policy, finance, culture, supports, human capital, and markets (Hwang and Horowitt, 2012; Isenberg, 2011). The results of this study include the identification of important stakeholders for supporting IDEs, such as providers of different forms of capital, universities, and research institutes. This study contributes to the existing body of knowledge by presenting an analysis of innovation-driven enterprises' development phases and typical stakeholders involved, as well as providing concrete examples of these stakeholders in San Diego and Oulu ICT innovation ecosystems. Furthermore, the innovation development phases were compared with the small company model developed by Churchill and Lewis (1983).

IDEs are recommended to exploit the spatial ecosystems by interacting with various stakeholders and by gaining access to local resources to create new innovations. The results of this study are relevant both for managers of new innovation-driven ventures and decision-makers responsible for local innovation policies. This research includes typical limitations of a case study, which makes generalisations difficult. Thus, further research in other spatial contexts is recommended to compare and validate the findings. For example, conducting a similar study in Asia could be a potential research topic in the future.

\section{References}

Aaltonen, K. and Kujala, J. (2010) 'A project lifecycle perspective on stakeholder influence strategies in global projects', Scandinavian Journal of Management, Vol. 26, No. 4, pp. 381-397.

Aulet, W. and Murray, F. (2013) 'A tale of two entrepreneurs: understanding differences in the types of entrepreneurship in the economy.' [online] http://dx.doi.org/10.2139/ssrn.2259740 (Accessed 17 May 2016).

Autio, E., Kenney, M., Mustar, P., Siegel, D. and Wright, M. (2014) 'Entrepreneurial innovation: the importance of context', Research Policy, Vol. 43, No. 7, pp. 1097-1108.

Belderbos, R., Carree, M. and Lokshin, B. (2004) 'Cooperative R\&D and firm performance', Research Policy, Vol. 33, No. 10, pp. 1477-1492.

BusinessOulu. (2015) Oulun seudun elinkeinokatsaus 2/2015, BusinessOulu.

Casper, S. (2013) 'New-technology clusters and public policy: three perspectives', Social Science Information, Vol. 52, No. 4, pp. 628-652.

Churchill, N.C. and Lewis, V.L. (1983) 'The five stages of small business growth', Harvard Business Review, Vol. 61, No. 3, pp. 30-50.

CONNECT. (2015) Innovation report 2014. [online] CONNECT, San Diego, California, USA. http://www.connect.org/innovation-reports (Accessed 17 May 2016)

Dermol, V. and Breznik, K. (2012) 'Innovation synergies through networking in Slovenian regions', International Journal of Synergy and Research, Vol. 1, No. 1, pp. 39-55.

Eisenhardt, K.M. (1989) 'Building theories from case study research', Academy of Management Review, Vol. 14, No. 4, pp. 532-550.

Etzkowitz, H. and Leydesdorf, L. (2000) 'The dynamics of innovation: from National Systems and "Mode 2 " to a Triple Helix of university-industry-government relations', Research policy, Vol. 29, No. 2, pp. 109-123.

Freeman, R.E. (1984) Strategic Management: a Stakeholder Approach, Pitman, Boston, USA.

Hwang, V.W. and Horowitt, G. (2012) The Rainforest: The Secret to Building the next Silicon Valley, Regenwald, Los Altos Hills, California, USA.

Iansiti, M. and Levien, R. (2004) 'Strategy as ecology', Harvard Business Review, Vol. 82, No. 3, pp. 68$78+126$. 


\section{Author}

Illés, C.B., Hurta, H. and Dunay, A. (2015) 'Efficiency and profitability along the lifecycle stages of small enterprises', International Journal of Management and Enterprise Development, Vol. 14, No. 1, pp.56-69.

Isenberg, D. (2011) 'Introducing the entrepreneurship ecosystem: four defining characteristics.' Forbes [online] 25 May. http://www.forbes.com/sites/danisenberg/2011/05/25/introducing-theentrepreneurship-ecosystem-four-defining-characteristics/\#2673504a38c43fea0a938c42 (Accessed 17 May 2016)

Kenney, M. (Ed.) (2000) Understanding Silicon Valley: the Anatomy of an Entrepreneurial Region, Stanford University Press, Stanford, California, USA.

Lehikoinen, M. (2015) Oulu, the ICT hotbed. [online] Finpro, Finland. http://www.oulu.fi/english/sites/default/files/Oulu\%20ICT\%20for\%20Uni\%20Oulu\%20international \%20students.pdf (Accessed 17 May 2016)

Majava, J., Isoherranen, V. and Kess, P. (2013) 'Business collaboration concepts and implications for companies', International Journal of Synergy and Research, Vol. 2, No. 1, pp. 23-40.

Majava, J., Leviäkangas, P., Kinnunen, T., Kess, P. and Foit, D. (2016) 'Spatial health and life sciences business ecosystem: a case study of San Diego', European Journal of Innovation Management, Vol. 19, No. 1, pp. 26-46.

Mitchell, R.K., Agle, B.R. and Wood, D.J. (1997) 'Toward a theory of stakeholder identification and salience: defining the principle of who and what really counts', Academy of Management Review, Vol. 22, No. 4, pp. 853-886.

Moore, J. F. (1993) 'Predators and prey: a new ecology of competition', Harvard Business Review, Vol. 71, No. 3, pp. 75-86.

Moore, J.F. (1996) The Death of Competition: Leadership \& Strategy in the Age of Business Ecosystems, HarperBusiness, New York, USA.

Muhos, M. (2015) 'Review of business growth models: methodology and the assumption of determinism', International Journal of Management and Enterprise Development, Vol. 14, No. 4, pp. 288-306.

OECD. (2014). Innovation indicators. [online] OECD. http://stats.oecd.org/Index.aspx?DataSetCode=REG_INNO_TL2 (Accessed 27 October 2014).

Oulu Innovation Alliance. [online] http://www.ouluinnovationalliance.fi/ (Accessed 17 May 2016).

Saarikoski, M., Roine, P., Ruohonen, J., Halonen, A., Sulin, J. and Lebret, H. (2014). Evaluation of Finnish Industry Investment Ltd, Publications of the Ministry of Employment and the Economy 1/2014.

Saxenian, A. (1996). Regional Advantage: Culture and Competition in Silicon Valley and Route 128, Harvard University Press, USA.

The City of San Diego [online] https://www.sandiego.gov/economic-development/sandiego/population (Accessed 17 May 2016).

UCSD [online] https://ucsd.edu/explore/about/index.html (Accessed 17 May 2016).

Ulrich, K. and Eppinger, S.D. (2012) Product Design and Development, McGraw Hill, Singapore.

Un, C.A., Cuervo-Cazurra, A. and Asakawa, K. (2010) 'R\&D collaborations and product innovation', Journal of Product Innovation Management, Vol. 27, No. 5, pp. 673-689.

Walshok, M. and Shragge, A. (2014) Invention and Reinvention: the Evolution of San Diego's Innovation Economy, Stanford University Press, Stanford, California, USA.

Walshok, M. and West, J. (2014) 'Serendipity and symbiosis: UCSD and the local wireless industry', in Kenney, M. and Mowery, D. (Eds.), Public Universities and Regional Growth: Insights from the University of California, Stanford University Press, Stanford, California, USA, pp. 127-152.

Yin, R.K. (2009) Case Study Research: Design and Methods, Sage Publications, Los Angeles, California, USA. 
Title

Appendix 1. PCT patent applications in Oulu region, San Diego area, and Silicon Valley (OECD, 2014)

\begin{tabular}{|c|c|c|c|c|c|c|}
\hline Variable & Region & 2006 & 2007 & 2008 & 2009 & 2010 \\
\hline \multirow{3}{*}{$\begin{array}{l}\text { PCT patent } \\
\text { applications per } \\
\text { million } \\
\text { inhabitants } \\
\text { (fractional } \\
\text { count; by } \\
\text { inventor and } \\
\text { priority year) - } \\
\text { level }\end{array}$} & $\begin{array}{l}\text { Northern } \\
\text { Ostrobothnia } \\
\text { (Oulu and } \\
\text { surrounding } \\
\text { region) }\end{array}$ & 404,4 & 401,6 & 363,3 & 418,7 & 412,6 \\
\hline & $\begin{array}{l}\text { San Diego- } \\
\text { Carlsbad-San } \\
\text { Marcos, CA }\end{array}$ & 763,0 & 847,2 & 910,4 & 916,8 & 665,4 \\
\hline & $\begin{array}{l}\text { San Jose-San } \\
\text { Francisco- } \\
\text { Oakland, CA } \\
\text { (Silicon Valley) }\end{array}$ & 674,6 & 663,4 & 576,6 & 565,5 & 543,4 \\
\hline \multirow[t]{3}{*}{$\begin{array}{l}\text { PCT patent } \\
\text { applications - } \\
\text { count }\end{array}$} & $\begin{array}{l}\text { Northern } \\
\text { Ostrobothnia } \\
\text { (Oulu and } \\
\text { surrounding } \\
\text { region) }\end{array}$ & 153,4 & 152,9 & 139,3 & 161,7 & 161,8 \\
\hline & $\begin{array}{l}\text { San Diego- } \\
\text { Carlsbad-San } \\
\text { Marcos, CA }\end{array}$ & 2248,6 & 2520,9 & 2751,3 & 2806,5 & 2066,7 \\
\hline & $\begin{array}{l}\text { San Jose-San } \\
\text { Francisco- } \\
\text { Oakland, CA } \\
\text { (Silicon Valley) }\end{array}$ & 6352,0 & 6294,1 & 5535,6 & 5492,2 & 5334,6 \\
\hline \multirow[t]{3}{*}{$\begin{array}{l}\text { PCT patent } \\
\text { applications in } \\
\text { ICT - count }\end{array}$} & $\begin{array}{l}\text { Northern } \\
\text { Ostrobothnia } \\
\text { (Oulu and } \\
\text { surrounding } \\
\text { region) }\end{array}$ & 120,1 & 99,4 & 88,9 & 90,4 & 84,0 \\
\hline & $\begin{array}{l}\text { San Diego- } \\
\text { Carlsbad-San } \\
\text { Marcos, CA }\end{array}$ & 1201,6 & 1356,4 & 1448,1 & 1539,3 & 1058,1 \\
\hline & $\begin{array}{l}\text { San Jose-San } \\
\text { Francisco- } \\
\text { Oakland, CA } \\
\text { (Silicon Valley) }\end{array}$ & 3780,9 & 3721,9 & 3190,6 & 3171,3 & 3273,1 \\
\hline
\end{tabular}

